\title{
Potential of an aqueous extract of Lippia multiflora Moldenke (Verbenaceae) in the treatment of anxiety disorders: Possible involvement of serotoninergic transmission
}

\author{
Joseph Ngaibi 1, ${ }^{*}$, Germain Sotoing Taiwe ${ }^{2}$, Jacqueline Stephanie Kameni Njapdounke ${ }^{1}$, Bigued ${ }^{1}$, Yvette \\ Nguezeye ${ }^{1,3}$, Neteydji Sidiki ${ }^{1}$ and Elisabeth Ngo Bum ${ }^{1,4}$ \\ ${ }^{1}$ Department of Biological Sciences, Faculty of Science, University of Ngaoundere, P.O. Box 454, Ngaoundere, Cameroon. \\ 2 Department of Zoology and Animal Physiology, Faculty of Science, University of Buea, Cameroon, P.O. Box 63, Buea, \\ Cameroon. \\ ${ }^{3}$ Centre for Research on Medicinal Plants and Traditional Medicine, Institute of Medical Research and Medicinal Plants \\ Studies, P.O. Box 13033, Yaounde, Cameroon. \\ ${ }^{4}$ Department of Biological Sciences, Faculty of Science, University of Maroua, P.O. Box 814, Maroua, Cameroon.
}

GSC Biological and Pharmaceutical Sciences, 2021, 14(03), 277-289

Publication history: Received on 10 February 2021; revised on 18 March 2021; accepted on 21 March 2021

Article DOI: https://doi.org/10.30574/gscbps.2021.14.3.0079

\begin{abstract}
Ethnopharmacological relevance: The leaves and stems of Lippia multiflora Moldenke (Verbenaceae) are used in traditional medicine to treat depression, anxiety and epilepsy.

Aim of the study: The present study investigated the anxiolytic-like effects of Lippia multiflora aqueous extracts in experimental models of anxiety.

Materials and methods: Elevated plus maze and open field tests were used to evaluate anxiety and exploratory behaviour. The possible mechanism of action of Lippia multiflora were investigated after pretreatment of animal with agonist and antagonist of serotonin receptors, such as: $\mathrm{mCPP}$, a partial agonist at the 5-HT2C receptors; Way-100635, a selective $5-\mathrm{HT}_{1 \mathrm{~A}}$ receptors antagonist; and $\mathrm{DOI}$, the $5-\mathrm{HT}_{2 \mathrm{~A}} / 2 \mathrm{C}$ receptors agonist. The levels of monoamine neurotransmitters were evaluated in the brain.
\end{abstract}

Results: In the elevated plus maze, Lippia multiflora increased the number of entries into and percentage of time in open arms, and reduced rearing, head dipping, and percentage of time in closed arms. These effects were blocked with the agonist and antagonist of serotonin receptors. In the open field, Lippia multiflora increased crossing and reduced rearing and defecation. The endogenous levels of noradrenaline, dopamine and serotonin in the brain homogenates remain comparable to that distilled water-treated animals.

Conclusion: It could be concluded that Lippia multiflora aqueous extracts, used in traditional medicine in Cameroon for the treatment of depression, anxiety and epilepsy seemed to possess anxiolytic properties in mice. These effects might be mediated by serotonin receptors, but not by modulation of the levels of monoamine neurotransmitters when the extract is administered once after one hour.

Keywords: Lippia multiflora; Anxiolytic; Serotonin receptors; Brain; Traditional medicine.

\footnotetext{
* Corresponding author: Joseph Ngaibi

Department of Biological Sciences, Faculty of Sciences, University of Ngaoundere, P.O. Box 454, Ngaoundere, Cameroon. 


\section{Introduction}

Anxiety disorders are among the most commons psychiatrics pathologies in the general population, with a total prevalence of $12 \%$ to $15 \%$ [1]. Anxiety is a psychological and physiological state characterized by somatic, emotional, cognitive and behavioural modifications $[2,3]$. In the past decades, anxiolytic agents have been developed to target specific brain neurotransmitter systems such as serotonin and GABA, which have been thought to play critical roles in anxiety disorders [4]. Many anxiolytic drugs have been developed that have fewer side effects than earlier agents such as benzodiazepines, barbiturates, and antidepressants $[5,6]$. The serotonin system is involved in mediating a variety of behaviours that are altered in anxiety disorders, including sleep, motor coordination, mood, and cognitive function [7]. Among serotoninergic agents, the selective serotonin reuptake inhibitors appear more generally effective in most of the anxiety disorders than the serotonin receptor subtype-selective antagonists currently available. The effects of serotonin in the brain are mediated through interaction with serotonin receptors located pre- and post-synaptically at serotoninergic nerve terminals and on serotoninergic nerve cell bodies throughout the central nervous system [7, 8]. Agonists of the 5- $\mathrm{HT}_{1 \mathrm{~A}}$ receptor have anxiolytic properties in both humans and animal models [9] and 5-HT $1 \mathrm{~A}$ receptor knockout mice show increased anxiety-like behaviour in a variety of conflict tests [10].

Lippia multiflora Moldenke (Verbenaceae) is a medicinal plant widely distributed in the northern Cameroon, traditionally used for the treatment of epilepsy and associated morbidities, such as anxiety, memory impairment, depression and insomnia $[11,12]$. According to Cameroonian traditional healers, the leaves and stems are the preferred part of Lippia multiflora used for the treatment of anxiety disorders, depression, memory impairment, and epilepsy [13]. Some species from Lippia family have received a great attention owing to their biological properties, including anxiolytic activity. Gonzalez-Trujano et al., demonstrated that Lippia graveolens extract exerts anxiolytic-like activity involving many kinds of constituents, mainly of the terpenoid and flavonoid nature [14]. However, there is no scientific data supporting the anxiolytic activity of Lippia multiflora and it preliminary phytochemical analysis.

Due to the presence of anxiolytic compounds in the extracts of some species of Lippia family, it is presumed that Lippia multiflora extracts might have a beneficial effect on anxiety disorders [14]. On the basis of these considerations, the elevated plus maze test was used to examine the possible anxiolytic-like effects of Lippia multiflora extract, and it interaction of with agonist and antagonist of serotonin receptors, such as: 1-(3-chlorophenyl) piperazine hydrochloride solution (mCPP), a partial agonist at the 5- $\mathrm{HT}_{2 \mathrm{C}}$ receptor but antagonized the 5- $\mathrm{HT}_{2 \mathrm{~B}}$ and 5 - $\mathrm{HT}_{3}$ receptors; $N$-[2-[4-(2methoxyphenyl)-1-piperazinyl] ethyl]- $N$-(2- pyridinyl) cyclohexanecarboxamide trihydrochloride (Way-100635), a selective 5-HT1A-receptor antagonist; and (-(+/-)-1-(2,5-dimethoxy-4-iodophenyl)-2-aminopropane; DOI, the 5-HT2A/2C agonist. After the open filed test, the relationship between anxiolytic like-properties of Lippia multiflora extracts and the neurochemical (dopamine, serotonin and noradrenaline) changes in the brain of animals were determined.

\section{Material and methods}

\subsection{Plant material}

The leaves and stems of Lippia multiflora were collected in Ngaoundere, area of the Adamawa Region of Cameroon, between January 2018 and March 2018. Specimen is preserved with a voucher vide specimen number 7753/SRF/Cam at the National Herbarium of Yaounde, Cameroon.

\subsection{Preparation of Lippia multiflora aqueous extracts}

Dried leaves and stems of Lippia multiflora were ground in a mill and $100 \mathrm{~g}$ of powder were obtained and put for maceration in $1000 \mathrm{~mL}$ of distilled water. After 3 hours, the macerate was boiled for 20 min. The supernatant was collected after cooling, and filtered with a Whatman number 1 filter paper (decoction or aqueous extract). The extract $(390 \mathrm{~mL}$ ) was evaporated in vacuo and $9.00 \mathrm{~g}$ aqueous extract were obtained. The yield of the extraction was $9.00 \%$. The obtained stock solution, or decoction of Lippia multiflora with a concentration of $23.078 \mathrm{mg} / \mathrm{mL}$ was administered to mice in a volume of $10 \mathrm{~mL} / \mathrm{kg}$ corresponding to a dose of $230.78 \mathrm{mg} / \mathrm{kg}$. This aqueous extract (decoction) was then diluted in distilled water, and three less concentration solutions $(2.307,5.769$ and $11.539 \mathrm{mg} / \mathrm{mL})$ were obtained.

\subsection{Preliminary phytochemical study}

Bufadienolides were screened in Lippia multiflora aqueous extract using a comparative thin layer chromatographic with anisaldehyde sulphuric acid reagent under UV (254-365 nm). For the other preliminary qualitative phytochemical analysis, alkaloid, flavonoid, triterpenoids, anthraquinones, saponins, phenols, reducing sugar were screened as described previously by Taiwe et al. [5]. 


\subsection{Chemicals}

Buspirone was purchased from Tocris Bioscience, United Kingdom, 1-(3-chlorophenyl) piperazine hydrochloride solution (mCPP), $N$-[2-[4-(2-methoxyphenyl)-1-piperazinyl] ethyl]- $N$-(2-pyridinyl) cyclohexanecarboxamide trihydrochloride (Way-100635) and (+/-)-1-(2,5-dimethoxy-4-iodophenyl)-2-aminopropane (DOI) were purchased from Sigma Chemical, USA. All reagents used for the quantification of the endogenous levels of noradrenaline, dopamine and serotonin in the brain homogenates were purchased from Sigma Chemical, USA.

\subsection{Animals}

Adult male Swiss mice (Mus musculus Swiss; 20 - 25 g) were used throughout these studies. They were obtained from the National Veterinary Laboratory, Garoua, Cameroon, and housed in standard cages at $25^{\circ} \mathrm{C}$ on a $12 \mathrm{~h} \mathrm{light-dark}$ cycle in the animal house of the Department of Biological Sciences, University of Ngaoundere, Cameroon. They were supplied with food and water ad libitum. The experiments were carried out in accordance with the National Ethical Committee Guidelines ( $\mathrm{N}^{\circ}$ FWA-IRB00001954) and International Guide for the Care and Use of Laboratory Animal (National Institute of Health; publication No. 85-23, revised 1996). All efforts were made to minimize both the suffering and number of animals used. The protocols for pharmacological studies, were also performed in compliance with the recommendations provided in the Animal Research: Reporting of In Vivo Experiment (ARRIVE) guidelines published online in PLOS Biology [15], and the general guidelines for experimental research and screening of traditional medicine as promulgated by WHO [16].

\subsection{Behavioural testing}

\subsubsection{Evaluation of anxiolytic properties in the elevated plus maze test}

The elevated plus maze test was performed according to the method previously described by Lister [17] with modifications. The plus maze consisted of two open arms $(16 \mathrm{~cm} \times 5 \mathrm{~cm})$ and two closed arms with a wall $(16 \mathrm{~cm} \times 5$ $\mathrm{cm} \times 10 \mathrm{~cm})$ connected to a central zone $(5 \times 5 \mathrm{~cm})$, forming a cross. It was elevated to a height of $50 \mathrm{~cm}$ from the floor. One hour before the elevated plus maze test, six groups of six animals each were administered orally with respectively Lippia multiflora aqueous extracts at the doses of 23.07, 57.69, 115.39 and $230.78 \mathrm{mg} / \mathrm{kg}$ for the test groups, buspirone at a dose of $10 \mathrm{mg} / \mathrm{kg}$ for the positive control group, or distilled water in a volume of $10 \mathrm{~mL} / \mathrm{kg}$, for the normal group. Each animal was placed individually at the centre of the elevated plus maze and their behaviours were recorded for 5 minutes duration [17-19]. The number of head dipping, grooming and the weight of faecal boli were recorded for each mouse. Additionally, the number of entries by each mouse into open or closed arms, and the time spent by each mouse in either open or closed arms were also observed and noted.

\subsubsection{Elucidation of the possible mechanisms of anxiolytic effects of Lippia multiflora aqueous extracts in the elevated plus maze test}

To demonstrate the possible participation of serotoninergic system in the anxiolytic-like activities of Lippia multiflora aqueous extracts, mice were pretreated agonist and antagonist of serotonin receptors 30 minutes prior to the treatment of animals with $230.78 \mathrm{mg} / \mathrm{kg}$ Lippia multiflora aqueous extract. Specifically, in each group of animals, mice were injected respectively with $7 \mathrm{mg} / \mathrm{kg}$ 1-(3-chlorophenyl) piperazine hydrochloride solution (mCPP), a partial agonist at the $5-\mathrm{HT}_{2 \mathrm{C}}$ receptor but antagonized the $5-\mathrm{HT}_{2 \mathrm{~B}}$ and $5-\mathrm{HT}_{3}$ receptors; $1 \mathrm{mg} / \mathrm{kg} N$-[2-[4-(2-methoxyphenyl)-1piperazinyl] ethyl]- $N$-(2- pyridinyl) cyclohexanecarboxamide trihydrochloride (Way-100635), a selective 5- $\mathrm{HT}_{1 \mathrm{~A}^{-}}$ receptor antagonist; and $1 \mathrm{mg} / \mathrm{kg}-(+/-)$-1-(2,5-dimethoxy-4-iodophenyl) -2-aminopropane (DOI), the 5-HT2A $/ 2 \mathrm{C}$ agonist, and $30 \mathrm{~min}$ post-treatment, mice were given orally $230.78 \mathrm{mg} / \mathrm{kg}$ Lippia multiflora aqueous extract, and 1 hour later, animals were subjected to the elevated plus maze test.

\subsubsection{Evaluation of locomotion and exploratory behaviour}

Open field test

One group of six mice received $10 \mathrm{~mL} / \mathrm{kg}$ of distilled water and served as a normal group, another group of six mice received buspirone $10 \mathrm{mg} / \mathrm{kg}$ and served as a positive control group. The other four groups received the four different doses of Lippia multiflora aqueous extracts $(23.07,57.69,115.39$ and $230.78 \mathrm{mg} / \mathrm{kg})$. The elevated plus maze assays was performed one hour after the treatment administration, and the ambulatory activity of each mouse was evaluated. In this test, a mouse was placed in the centre of the open field which is consist of a wooden square box $(40 \times 40 \times 45$ $\mathrm{cm}$ ). The number of crossing (number of square floor units entered), grooming, rearing (number of times the animal stood on its hind legs) and the weight of faecal boli (defecation) were recorded for each animal [19] were evaluated for 5 minutes duration. At the end of behavioural evaluations, each animal was euthanized by inhalation of high 
concentration of compressed carbon dioxide $\left(\mathrm{CO}_{2}\right)$ gas in cylinders, and the whole brain was collected for biochemical analyses. The brain samples were prepared in $25 \mathrm{ng} / \mathrm{ml}$ dihydroxybenzylamine). The mixtures were then homogenised in $0.17 \mathrm{M}$ perchloric acid. Finally, they were centrifugated at $35,000 \mathrm{~g}$ at $4^{\circ} \mathrm{C}$ and the supernatant were filtered and used for biochemical analysis [20].

Biochemical analyses: estimation of monoamine

The endogenous levels of noradrenaline, dopamine, and serotonin were determined in the brain homogenates by reverse phase high-pressure liquid chromatography with electrochemical detection [20]. The sample (10 mL) was injected via a HPLC pump (AKTA ${ }^{\mathrm{TM}}$ Purifier, Amersham Biosciences) into a Vydac C18 column $(218 \mathrm{TP} 1010,25 \times 10 \mathrm{~cm}$, $10 \mu \mathrm{m}$ ) connected to an electrochemical detector (Model 2465, Waters, Milford, MA, USA). Oxidation potential was fixed at $0.80 \mathrm{~V}$ using a glass carbon working electrode versus an $\mathrm{Ag} / \mathrm{AgCl}$ reference electrode. The mobile phase consisted of $32 \mathrm{mM}$ citric acid, $12.5 \mathrm{mM}$ disodium hydrogen orthophosphate, $1.4 \mathrm{mM}$ sodium octanyl sulphonate, $0.05 \mathrm{mM}$ EDTA and 16 per cent $(\mathrm{v} / \mathrm{v})$ methanol. The $\mathrm{pH}$ of the mobile phase was adjusted to 4.05. Separation was carried out at a flow rate of $1.2 \mathrm{~mL} / \mathrm{min}$. The neurotransmitters were quantified using Breeze version 3.2. The levels were expressed in ng/g wet tissue. Ratios of metabolite/amine were calculated as an index of turnover for dopamine and serotonin. All the quantification of the level of noradrenaline, dopamine, and serotonin was made by comparing peak heights of the samples to the corresponding standard curve.

\subsection{Statistical analysis}

Data are expressed as means \pm Standard Error of the Mean (S.E.M.) or as percentages of entries or time spent for each mouse. The data were compared using one or two-way analysis of variance (ANOVA) followed by Tukey's post hoc multiple comparison tests (whichever is applicable). P values less than 0.05 were considered as significant.

\section{Results and discussion}

\subsection{Phytochemical characterization of Lippia multiflora aqueous extracts}

As indicated by the thin layer Chromatography of Lippia multiflora aqueous extract, bufadienolides are absent. The preliminary phytochemical studies demonstrated that the Lippia multiflora aqueous extract contained: alkaloid, flavonoid, triterpenoids, glycosides, anthraquinones, saponins and phenols.

\subsection{Effects of Lippia multiflora aqueous extracts on anxiety-like behaviours in the elevated plus maze test}

3.2.1. Effects of Lippia multiflora aqueous extracts on the number of open arm entries, close arm entries, total arm entries, rearing, head dipping and faecal boli

Mice treated with Lippia multiflora aqueous extracts made more open entries $[\mathrm{F}(5,34)=53.18$, $\mathrm{p}<0.01]$ and spent a longer time in the open arms $[\mathrm{F}(5,42)=105.73, \mathrm{p}<0.001]$ of the elevated plus maze than the vehicle treated group. Interestingly, ANOVA revealed that the number of total arm entries $[\mathrm{F}(5,42)=131.17, \mathrm{p}<0.05]$ and the ratio $\mathrm{OE} / \mathrm{TE}$ versus $\mathrm{CE} / \mathrm{TE}[\mathrm{F}(5,42)=81.35, \mathrm{p}<0.001]$ are significant difference between the group treated with the different doses of extracts and distilled water treated group. Administration of Lippia multiflora significantly decrease the number of rearing from $12.83 \pm 1.05$ in the distilled water-treated group to1.50 \pm 0.43 in the group administered $230.78 \mathrm{mg} / \mathrm{kg}$ aqueous extracts. Additionally, the numbers of head dipping and faecal boli were reduced by Lippia multiflora aqueous extract and buspirone (10 mg/kg) (Table 1). 
Table 1 Effects of Lippia multiflora aqueous extracts on the number of open arm entries, close arm entries, total arm entries, rearing, head dipping and faecal boli in mice placed in the elevated plus maze.

\begin{tabular}{|l|l|l|l|l|l|l|l|l|}
\hline Treatments & $\begin{array}{l}\text { Doses } \\
\text { (mg/kg) }\end{array}$ & $\begin{array}{l}\text { Open arm } \\
\text { entries }\end{array}$ & $\begin{array}{l}\text { Close arm } \\
\text { entries }\end{array}$ & $\begin{array}{l}\text { Total arm } \\
\text { entries }\end{array}$ & $\begin{array}{l}\text { Ratio OE/TE vs } \\
\text { CE/TE }\end{array}$ & Rearing \\
\hline DW & -- & $0.67 \pm 0.44$ & $2.67 \pm 0.44$ & $3.33 \pm 0.44$ & $25.00 \pm 2.23$ & $12.83 \pm 1.05$ & $3.50 \pm 0.43$ & $0.23 \pm 0.10$ \\
\hline Lm23.07 & 23.07 & $1.33 \pm 0.44$ & $2.33 \pm 0.78$ & $3.67 \pm 0.89$ & $57.14 \pm 13.24^{\mathrm{a}}$ & $11.17 \pm 1.05$ & $2.83 \pm 0.56$ & $0.10 \pm 0.03^{\mathrm{c}}$ \\
\hline Lm57.69 & 57.69 & $2.17 \pm 0.61^{\mathrm{a}}$ & $1.83 \pm 0.56^{\mathrm{a}}$ & $4.00 \pm 1.00$ & $118.18 \pm 12.71^{\mathrm{c}}$ & $8.50 \pm 0.86^{\mathrm{a}}$ & $1.83 \pm 0.28^{\mathrm{a}}$ & $0.04 \pm 0.05^{\mathrm{c}}$ \\
\hline Lm115.39 & 115.39 & $3.83 \pm 0.89^{\mathrm{b}}$ & $1.66 \pm 0.78^{\mathrm{a}}$ & $5.50 \pm 1.00^{\mathrm{a}}$ & $230.00 \pm 22.14^{\mathrm{c}}$ & $3.83 \pm 1.10^{\mathrm{b}}$ & $1.50 \pm 0.83^{\mathrm{a}}$ & $0.04 \pm 0.05^{\mathrm{c}}$ \\
\hline Lm230.78 & 230.78 & $4.83 \pm 1.17^{\mathrm{c}}$ & $1.33 \pm 0.44^{\mathrm{a}}$ & $6.17 \pm 1.22^{\mathrm{a}}$ & $362.50 \pm 36.51^{\mathrm{c}}$ & $1.50 \pm 0.43^{\mathrm{c}}$ & $0.67 \pm 0.44^{\mathrm{b}}$ & $0.02 \pm 0.03^{\mathrm{c}}$ \\
\hline Bus & 10 & $5.33 \pm 1.1^{\mathrm{c}}$ & $1.17 \pm 0.28^{\mathrm{a}}$ & $6.50 \pm 1.33^{\mathrm{a}}$ & $457.14 \pm 47.94^{\mathrm{c}}$ & $1.33 \pm 0.38^{\mathrm{c}}$ & $0.50 \pm 0.50^{\mathrm{b}}$ & $0.01 \pm 0.03^{\mathrm{c}}$ \\
\hline
\end{tabular}

Results are expressed as mean \pm S.E.M., for 6 animals. Data were analysed by one-way ANOVA, followed by Tukey's (HSD) multiple comparison test, aP $<0.05$, bP $<0.01$, cP $<0.001$, significantly different compared to the negative control group treated with distilled water. Lm23.07, 23.07 mg/kg Lippia multiflora aqueous extract; DW, distilled water; Bus, $10 \mathrm{mg} / \mathrm{kg}$ buspirone; OE, open entries; TE, total entries; CE, close entries.

Table 2 Effects of pretreatment with mCPP, WAY, and DOI on behavioural ameliorations induced by Lippia multiflora aqueous extract in the elevated plus maze test.

\begin{tabular}{|c|c|c|c|c|c|c|c|c|}
\hline Treatments & $\begin{array}{l}\text { Doses } \\
(\mathrm{mg} / \mathrm{kg})\end{array}$ & $\begin{array}{l}\text { Open arm } \\
\text { entries }\end{array}$ & $\begin{array}{l}\text { Close arm } \\
\text { entries }\end{array}$ & $\begin{array}{l}\text { Total arm } \\
\text { entries }\end{array}$ & $\begin{array}{l}\text { Ratio OE/TE vs } \\
\text { CE/TE }\end{array}$ & Rearing & $\begin{array}{l}\text { Head } \\
\text { dipping }\end{array}$ & Faecal boli \\
\hline DW & -- & $0.67 \pm 0.44 \gamma$ & $2.67 \pm 0.44^{\alpha}$ & $3.33 \pm 0.44^{\alpha}$ & $25.00 \pm 2.23 \gamma$ & $12.83 \pm 1.05 \gamma$ & $3.50 \pm 0.43 \gamma$ & $0.23 \pm 0.10 \gamma$ \\
\hline Lm230.78 & 230.78 & $4.83 \pm 1.17 c$ & $1.33 \pm 0.44^{\mathrm{a}}$ & $6.17 \pm 1.22^{\mathrm{a}}$ & $362.50 \pm 36.51^{c}$ & $1.50 \pm 0.43^{c}$ & $0.67 \pm 0.44^{c}$ & $0.02 \pm 0.03^{c}$ \\
\hline Lm230.78+mCPP & $230.78+7$ & $1.67 \pm 0.44 \gamma$ & $2.33 \pm 0.67^{\alpha}$ & $4.50 \pm 0.50^{\alpha}$ & $58.82 \pm 3.52^{\mathrm{a} \gamma}$ & $10.66 \pm 1.61^{\gamma}$ & $3.50 \pm 0.67 \gamma$ & $0.58 \pm 0.21^{\gamma}$ \\
\hline Lm230.78+WAY & $230.78+1$ & $1.83 \pm 0.28 \gamma$ & $2.50 \pm 0.67^{\alpha}$ & $4.17 \pm 0.56^{\alpha}$ & $78.57 \pm 6.12^{\mathrm{a} \gamma}$ & $10.67 \pm 1.52^{\gamma}$ & $3.17 \pm 0.83^{\beta}$ & $0.40 \pm 0.27 \gamma$ \\
\hline Lm230.78+DOI & $230.78+1$ & $1.67 \pm 0.67 \gamma$ & $2.50 \pm 0.67^{\alpha}$ & $4.17 \pm 0.83^{\alpha}$ & $66.67 \pm 4.81^{\mathrm{a} \gamma}$ & $11.83 \pm 1.04 \gamma$ & $3.33 \pm 0.67 \gamma$ & $0.52 \pm 0.23 \gamma$ \\
\hline
\end{tabular}

Results are expressed as mean \pm S.E.M., for 6 animals. Data were analysed by one-way ANOVA, followed by Tukey's (HSD) multiple comparison test, ${ }^{\text {aP }}<0.05$, cP $<0.001$, significantly different compared to distilled water-treated group, ${ }^{\alpha} \mathrm{P}<0.05, \beta \mathrm{P}<0.01, \mathrm{\gamma}<0.001$, significantly different compared to $230.78 \mathrm{mg} / \mathrm{kg}$ Lippia multiflora aqueous extract-treated group. DW, distilled water; Lm23.07, $230.78 \mathrm{mg} / \mathrm{kg}$ Lippia multiflora aqueous extracts; mCPP, $7 \mathrm{mg} / \mathrm{kg} 1$-(3-chlorophenyl) piperazine hydrochloride solution; WAY, $1 \mathrm{mg} / \mathrm{kg} \mathrm{N}$-[2-[4-(2-methoxyphenyl)-1-piperazinyl] ethyl]- $N$-(2- pyridinyl) cyclohexanecarboxamide trihydrochloride; DOI, $1 \mathrm{mg} / \mathrm{kg}-(+/-)-1-(2,5-$ dimethoxy-4-iodophenyl) -2-aminopropane 


\subsubsection{Effects of Lippia multiflora aqueous extracts on the percentages of open arm entries and time}

The anti-anxiety profile showing the percentage of open arm entries and time spent in the open arms of the vehicle, various doses of Lippia multiflora aqueous extracts and the standard drug buspirone are depicted in Figures 1, respectively. The extracts at a dose of $230.78 \mathrm{mg} / \mathrm{kg}$ and buspirone $10 \mathrm{mg} / \mathrm{kg}$ significantly increased the percentage of open arm entries $(\mathrm{p}<0.01$ and $\mathrm{p}<0.001$, respectively), while significantly reducing the time spent in the open arms $(\mathrm{p}<0.01$ and $\mathrm{p}<0.001$, respectively) compared with the negative control group treated with distilled water.

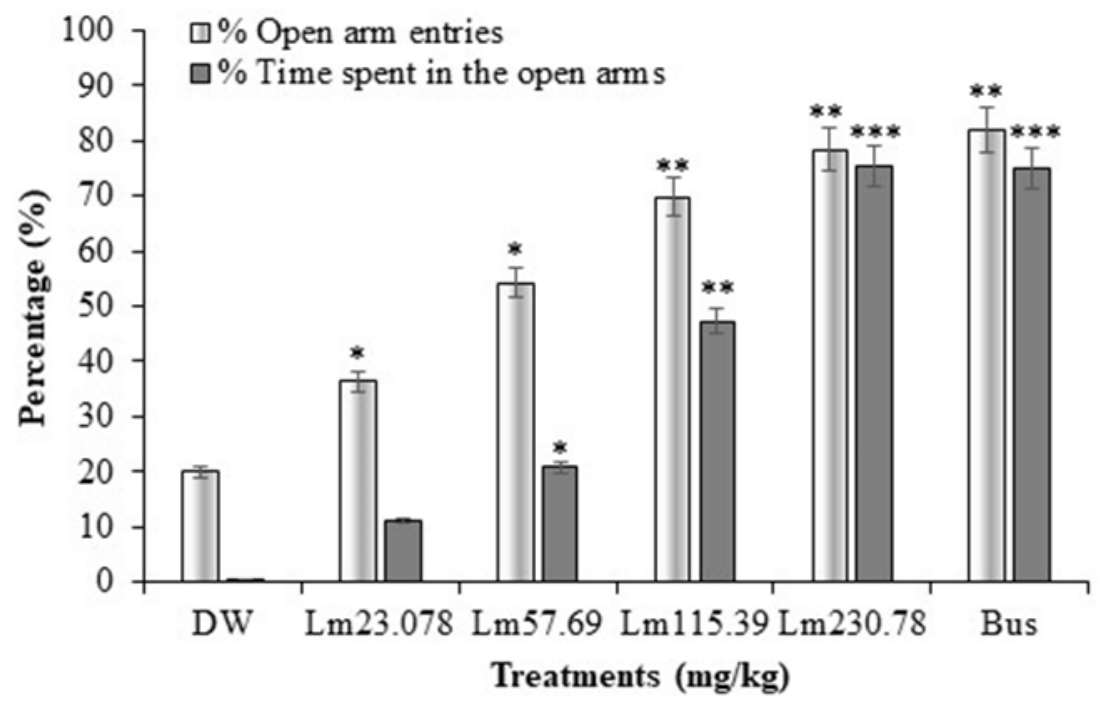

Figure 1 Effect of Lippia multiflora aqueous extracts on mice placed in the elevated plus maze: percentage of open arm entries and time in open arm.

Shown are the percentage of open arm entries/total arm entries and the percentage of open arm time/session time (5 minutes), for 6 animals. Data were analysed by one-way ANOVA, followed by Tukey's (HSD) multiple comparison test, ${ }^{*} \mathrm{p}<0.05,{ }^{* *} \mathrm{p}<0.01,{ }^{* *} \mathrm{p}<0.001$, significantly different compared to the negative control group. DW, distilled water; Lm23.07, 23.07 mg/kg Lippia multiflora aqueous extracts; Bus, 10 mg/kg buspirone.

\subsubsection{Effects of Lippia multiflora aqueous extracts on the percentage of close arm entries and time}

Compared with distilled water, Lippia multiflora aqueous extracts resulted in a significant decrease in the percentage of close arm entries $[F(5,25)=94.13, p<0.001]$ and time spent in close arms $[F(5,48)=78.15$, $p<0.001]$ of the elevated plus maze. As expected for the reference drug, $10 \mathrm{mg} / \mathrm{kg}$ buspirone also induced a significant decrease in the percentage of entries into and time spent in the close arms of the elevated plus maze. Oral administration of Lippia multiflora aqueous extracts induced a significant reduction in the percentage of entries into closed arms from $88.00 \%$ in the distilled water-treated group to $30.30 \%(\mathrm{p}<0.05)$ and $21.62 \%(\mathrm{p}<0.001)$ in the test groups treated with the respective doses of 115.39 and $230.78 \mathrm{mg} / \mathrm{kg}$ Lippia multiflora aqueous extracts. There is a significant reduction in the percentage of time spent in closed arms $[\mathrm{F}(5,283)=105.32, \mathrm{p}<0.001]$ of the elevated plus maze for the groups of animal administered Lippia multiflora aqueous extracts and the anxiolytic drug buspirone (10 mg/kg) (Figure 2). 


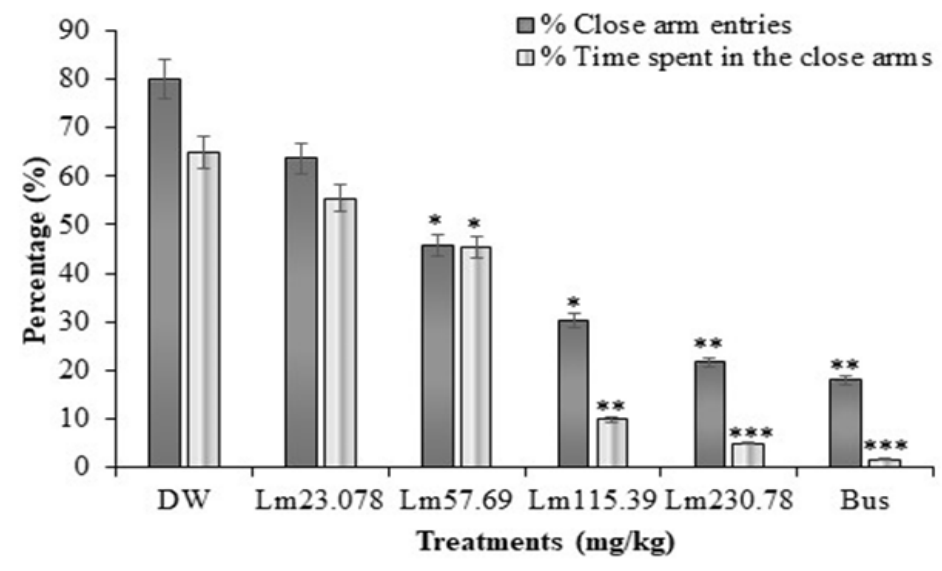

Figure 2 Effects of Lippia multiflora aqueous extracts on mice placed in the elevated plus maze: percentage of close arm entries and time in close arms.

Shown are the percentage of close arm entries/total arm entries and the percentage of close arm time/session time (5 minutes), for 6 animals. Data were analysed by one-way ANOVA, followed by Tukey's (HSD) multiple comparison test, ${ }^{*} \mathrm{p}<0.05,{ }^{* *} \mathrm{p}<0.01,{ }^{* * *} \mathrm{p}<0.001$, significantly different compared to the negative control group. DW, distilled water; Lm23.07, 23.07 mg/kg Lippia multiflora aqueous extracts; Bus, 10 mg/kg buspirone.

\subsection{Participation of serotoninergic pathway in anxiolytic-like effect of Lippia multiflora aqueous extracts}

3.3.1. Effects of pretreatment with $m C P P, W A Y$, and DOI on behavioural ameliorations induced by Lippia multiflora aqueous extract in the elevated plus maze test

As shown in Table 2, administration of $230.78 \mathrm{mg} / \mathrm{kg}$ Lippia multiflora aqueous extract induced an anxiolytic-like activity in the elevated plus maze test. These effects were blocked by $7 \mathrm{mg} / \mathrm{kg} \mathrm{mCPP,} 1 \mathrm{mg} / \mathrm{kg}$ WAY and $1 \mathrm{mg} / \mathrm{kg}$ DOI pretreatment as shown in Table 2. The two-way ANOVA indicated a main effect of $230.78 \mathrm{mg} / \mathrm{kg} \mathrm{Lippia} \mathrm{multiflora}$ aqueous extract treatment $[\mathrm{F}(4,27)=105.32, \mathrm{p}<0.001]$, and $7 \mathrm{mg} / \mathrm{kg} \mathrm{mCPP}$ pretreatment $\times 230.78 \mathrm{mg} / \mathrm{kg} \mathrm{Lippia}$ multiflora aqueous extract treatment interaction $[\mathrm{F}(4,27)=72.46, \mathrm{p}<0.001]$ for the number of open arm entries in the elevated plus maze (Table 2). Two-way ANOVA revealed significant differences in the number of entries in the elevated plus maze for a dose of $230.78 \mathrm{mg} / \mathrm{kg}$ Lippia multiflora aqueous extract treatment $[\mathrm{F}(4,28)=52.87$, $\mathrm{p}<0.001]$, and 1 $\mathrm{mg} / \mathrm{kg}$ WAY pretreatment $\times 230.78 \mathrm{mg} / \mathrm{kg}$ Lippia multiflora aqueous extract treatment interaction $[\mathrm{F}(4,28)=102.34$, $\mathrm{p}<0.05]$. Interestingly, as indicated in Table 2, the two-way ANOVA revealed a main effect of $230.78 \mathrm{mg} / \mathrm{kg} \mathrm{Lippia}$ multiflora aqueous extract treatment $[\mathrm{F}(4,28)=151.32$, $\mathrm{p}<0.05]$, and $1 \mathrm{mg} / \mathrm{kg}$ DOI pretreatment $\times 230.78 \mathrm{mg} / \mathrm{kg}$ Lippia multiflora aqueous extract treatment interaction $[\mathrm{F}(4,28)=95.28, \mathrm{p}<0.05]$ for the number of close arm entries.

3.3.2. Effects of pretreatment with $m C P P, W A Y$, and DOI on amelioration in the percentages of open arms entries and timeinduced by Lippia multiflora aqueous extract in the elevated plus maze

Post hoc test indicated that the percentage of open arms entries and time spent in the open arms are significantly increased in group of animals treated with $230.78 \mathrm{mg} / \mathrm{kg}$ Lippia multiflora aqueous extract as depicted in Figure 3. However, these increases are significantly antagonised by $7 \mathrm{mg} / \mathrm{kg} \mathrm{mCPP,} 1 \mathrm{mg} / \mathrm{kg}$ WAY, or $1 \mathrm{mg} / \mathrm{kg}$ DOI pretreatment as shown in Figure 3. 


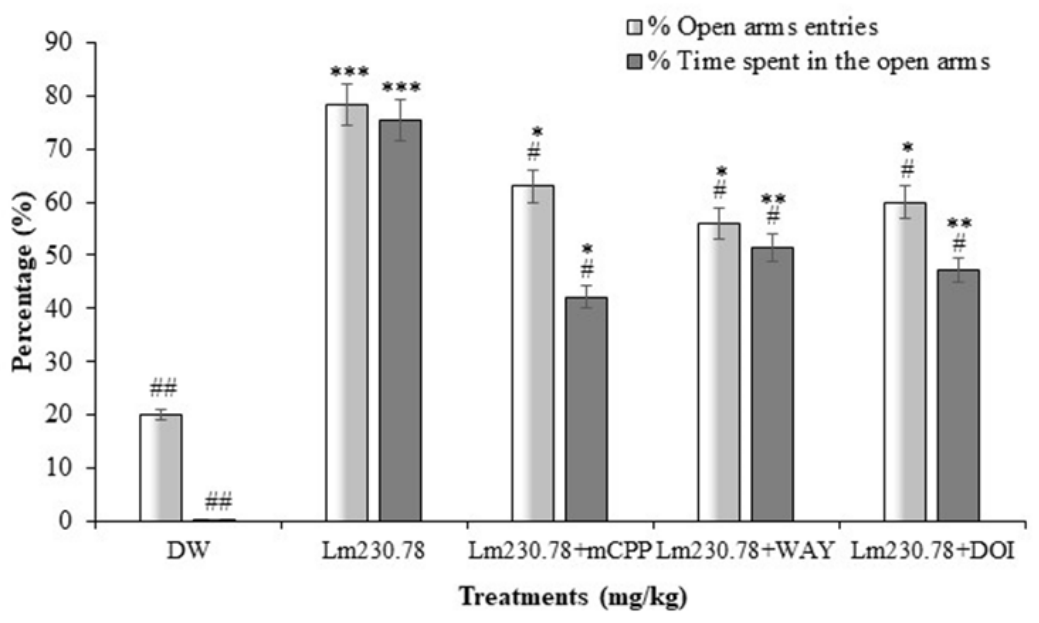

Figure 3 Effects of pretreatment with mCPP, WAY, and DOI on ameliorations in the percentages of open arms entries and time-induced by Lippia multiflora aqueous extract in the elevated plus maze

Shown are the percentage of open arm entries/total arm entries and the percentage of open arm time/session time (5 minutes), for 6 animals. Data were analysed by ANOVA, followed by Tukey's (HSD) multiple comparison test, $* \mathrm{P}<0.05$, ${ }^{* *} \mathrm{P}<0.01$, ${ }^{* * *} \mathrm{P}<0.001$, significantly different compared to distilled water-treated group, ${ }^{\#} \mathrm{P}<0.05$, ${ }^{\# \#} \mathrm{P}<0.01$, significantly different compared to $230.70 \mathrm{mg} / \mathrm{kg}$ Lippia multiflora aqueous extract-treated group. DW, distilled water; Lm230.70, $230.70 \mathrm{mg} / \mathrm{kg}$ Lippia multiflora aqueous extracts; mCPP, $7 \mathrm{mg} / \mathrm{kg}$ 1-(3-chlorophenyl) piperazine hydrochloride solution; WAY, $1 \mathrm{mg} / \mathrm{kg} \mathrm{N}$-[2-[4-(2-methoxyphenyl)-1-piperazinyl] ethyl]- $N$-(2- pyridinyl) cyclohexanecarboxamide trihydrochloride; DOI, $1 \mathrm{mg} / \mathrm{kg}-(+/-)-1-(2,5-$ dimethoxy-4-iodophenyl) -2-aminopropane.

3.3.3. Effects of pretreatment with $\mathrm{mCPP}, W A Y$, or DOI on amelioration in the percentages of close arms entries and timeinduced by Lippia multiflora aqueous extract in the elevated plus maze

The decrease in the percentage of close arms entries and time induced by Lippia multiflora aqueous extract administered at a dose of $230.78 \mathrm{mg} / \mathrm{kg}$ was significantly blocked by $7 \mathrm{mg} / \mathrm{kg} \mathrm{mCPP,} 1 \mathrm{mg} / \mathrm{kg} \mathrm{WAY,} \mathrm{or} 1 \mathrm{mg} / \mathrm{kg} \mathrm{DOI}$ pretreatment as indicated in Figure 4.

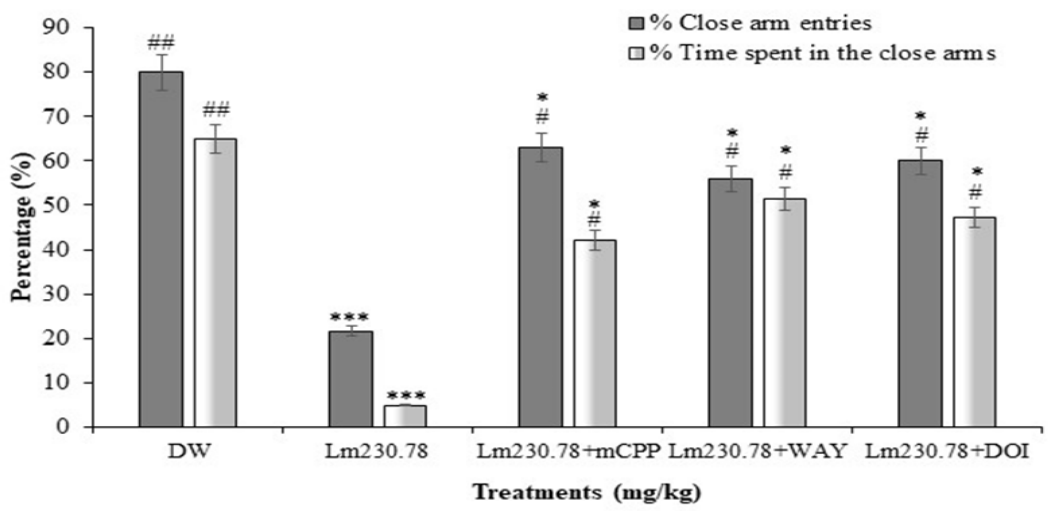

Figure 4 Effects of pretreatment with mCPP, WAY, or DOI on ameliorations in the percentages of close arms entries and time-induced by Lippia multiflora aqueous extract in the elevated plus maze

Shown are the percentage of open arm entries/total arm entries and the percentage of open arm time/session time (5 minutes), for 6 animals. Data were analysed by ANOVA, followed by Tukey's (HSD) multiple comparison test, *P<0.05, ${ }^{* * *} \mathrm{P}<0.001$, significantly different compared to distilled water-treated group, ${ }^{\#} \mathrm{P}<0.05,{ }^{\#} \mathrm{P}<0.01$, significantly different compared to $230.70 \mathrm{mg} / \mathrm{kg}$ Lippia multiflora aqueous extract-treated group. DW, distilled water; Lm230.70, 230.70 $\mathrm{mg} / \mathrm{kg}$ Lippia multiflora aqueous extracts; mCPP, $7 \mathrm{mg} / \mathrm{kg} 1-(3-$ chlorophenyl) piperazine hydrochloride solution; WAY, $1 \mathrm{mg} / \mathrm{kg} \mathrm{N}$-[2-[4-(2-methoxyphenyl)-1-piperazinyl] ethyl]- $N$-(2-pyridinyl) cyclohexanecarboxamide trihydrochloride; DOI, $1 \mathrm{mg} / \mathrm{kg}-(+/-)$-1-(2,5-dimethoxy-4-iodophenyl) -2-aminopropane. 


\subsection{Effects of Lippia multiflora aqueous extracts on exploratory behaviour and locomotion in the open field test}

One way ANOVA revealed that Lippia multiflora aqueous extracts $(23.07-230.78 \mathrm{mg} / \mathrm{kg})$ treatment did affect; the number of rearing $[F(5,24)=104.73, p<0.001]$, crossing $[F(5,24)=74.15, p<0.05]$ and grooming $[F(5,24)=84.36$, $\mathrm{p}<0.05]$ behaviours, faecal boli $[\mathrm{F}(5,24)=104.15, \mathrm{p}<0.001]$ and centre time $[\mathrm{F}(5,28)=35.15$, $\mathrm{p}<0.001]$ made by the animal in the open field test as compared to control, distilled water-treated mice (Table 3), indicating that the anxiolyticlike effect of Lippia multiflora aqueous extracts in the elevated plus maze test is not due to its psychostimulant activity, thus ruling out false positive or negative results.

Table 3 Effects of Lippia multiflora aqueous extracts on the number of rearing, crossing, grooming, the centre time and the quantity of faecal boli in the open field test.

\begin{tabular}{|l|l|l|l|l|l|l|}
\hline Treatments & Doses (mg/kg) & Rearing & Crossing & Grooming & Faecal boli & Centre time \\
\hline DW & -- & $9.17 \pm 1.17$ & $17.83 \pm 4.83$ & $2.67 \pm 0.67$ & $0.42 \pm 0.28$ & $2.33 \pm 0.78$ \\
\hline Lm23.07 & 23.07 & $4.83 \pm 1.22^{c}$ & $16.67 \pm 1.67$ & $4.62 \pm 0.67^{\mathrm{a}}$ & $0.17 \pm 0.03^{\mathrm{a}}$ & $9.33 \pm 1.67^{\mathrm{a}}$ \\
\hline Lm57.69 & 57.69 & $3.67 \pm 0.44^{\mathrm{c}}$ & $17,33 \pm 2.44$ & $4.83 \pm 0.89^{\mathrm{a}}$ & $0.08 \pm 0.08^{\mathrm{b}}$ & $14.83 \pm 1.83^{\mathrm{c}}$ \\
\hline Lm115.39 & 115.39 & $1.83 \pm 0.56^{\mathrm{c}}$ & $20.33 \pm 2.33^{\mathrm{a}}$ & $5.33 \pm 0.44^{\mathrm{a}}$ & $0.07 \pm 0.08^{\mathrm{b}}$ & $22.67 \pm 3.78^{\mathrm{c}}$ \\
\hline Lm230.78 & 230.78 & $1.83 \pm 0.28^{\mathrm{c}}$ & $22.67 \pm 3.11^{\mathrm{a}}$ & $5.50 \pm 0.50^{\mathrm{a}}$ & $0.05 \pm 0.05^{\mathrm{b}}$ & $28.17 \pm 1.56^{\mathrm{c}}$ \\
\hline Bus & 10 & $1.50 \pm 0.50^{\mathrm{c}}$ & $24.83 \pm 6.17^{\mathrm{a}}$ & $5.33 \pm 0.44^{\mathrm{a}}$ & $0.03 \pm 0.05^{\mathrm{c}}$ & $36.33 \pm 4.11^{\mathrm{c}}$ \\
\hline
\end{tabular}

Results are expressed as mean \pm S.E.M., for 6 animals. Data were analysed by one-way ANOVA, followed by Tukey's (HSD) multiple comparison test, $\mathrm{a}<<0.05, \mathrm{~b}<<0.01, \mathrm{P}<0.001$, significantly different compared to the significantly different compared to the negative control group. $\mathrm{DW}$, distilled water; Lm23.07, $23.07 \mathrm{mg} / \mathrm{kg}$ Lippia multiflora aqueous extracts; Bus, $10 \mathrm{mg} / \mathrm{kg}$ buspirone.

\subsection{Effects of Lippia multiflora aqueous extracts the level of noradrenaline, dopamine and serotonin level in the brain homogenate after the open field test}

Acute oral administration of Lippia multiflora aqueous extracts at the doses ranged from 23.70 to $230.78 \mathrm{mg} / \mathrm{kg}$ or 10 $\mathrm{mg} / \mathrm{kg}$ buspirone did not significantly modify the endogenous levels of noradrenaline $[\mathrm{F}(5,24)=73.28, \mathrm{p}>0.05]$, dopamine $[F(5,24)=48.13, p>0.05]$, and serotonin $[F(5,24)=64.91, p>0.05]$ in the brain homogenates one hours after treatment and the subjection to the open field test.

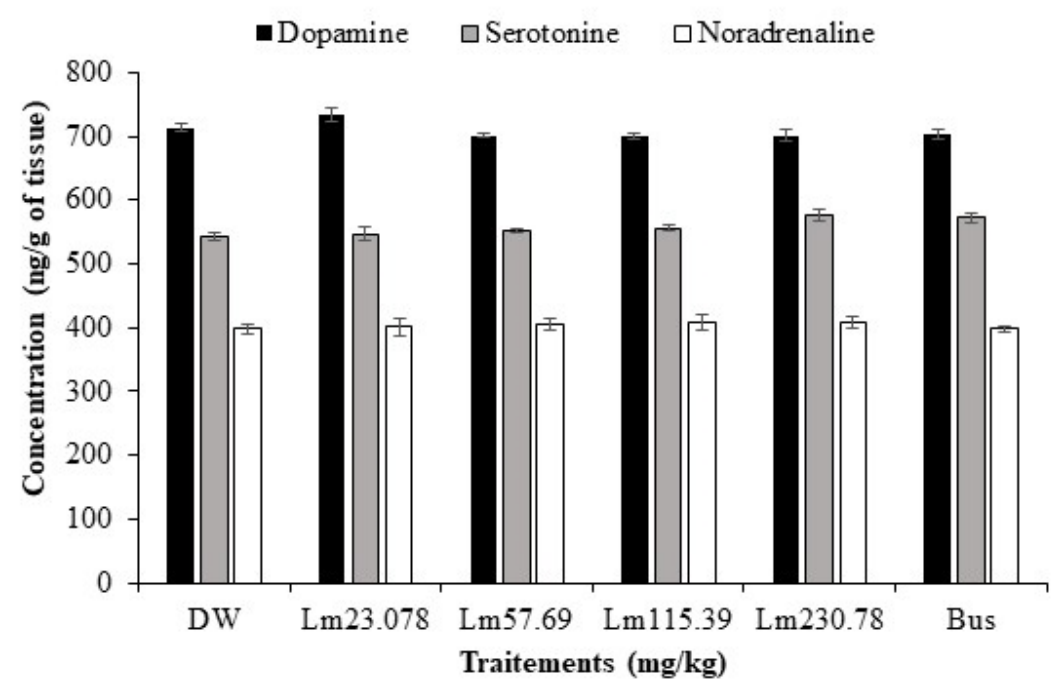

Figure 5 Effects of Lippia multiflora aqueous extracts on the level of noradrenaline, dopamine and serotonin in the brain homogenate

Results are expressed as mean \pm S.E.M., for 6 animals. Data were analysed by one-way ANOVA, followed by Tukey's (HSD) multiple comparison test, there is no significant difference between the different groups of animals. DW, distilled water; Lm23.07, 23.07 mg/kg Lippia multiflora aqueous extracts; Bus, 10 mg/kg buspirone. 


\section{Discussion}

In the therapy of anxiety disorder or acute generalised anxiety symptoms, a combination of therapeutic interventions is mostly appreciated and indicated. Beside a psychotherapeutic approach, anxiolytic drugs are a part of the treatment of anxiety [21]. There is considerable interest in the development of new anxiolytic drugs, and new therapies for the management of anxiety disorders are necessary. However, self-administration of medicinal plants was among the most popular of alternative therapies. Therefore, the study of medicinal plants could provide new therapeutic options [22]. Quantitative phytochemical study of Lippia multiflora aqueous extract indicated the presence of alkaloid, flavonoid, triterpenoids, glycosides, anthraquinones, saponins and phenols. Flavonoids are considered as secondary plant metabolites that have a wide range of biological activities, such as anti-inflammatory, antioxidant and neuroprotective effects, and readily cross the blood-brain barrier [23]. Flavonoids are polyphenols found in many natural products such as medicinal plant families and obtained from leaves, stems, roots or barks. Consumption of these parts known to be rich in flavonoids has been reported to result in anti-anxiety effect [24, 25]. In addition to the anxiolytic effect, flavonoids were shown to prevent neuro-degeneration [26]. The obtained data from this research illustrated that the extract may provide an alternative treatment for neurological disorders such as anxiety and depression.

Anxiety and fear can be induced in rodents by the novelty of a situation. They can be evaluated in mice by determining the frequency and the intensity of behaviour in an unfamiliar area [27]. The elevated plus maze is based on rodents' natural aversion to height and open spaces $[17,27]$. The elevated plus maze is considered an ethologically valid animal model of anxiety because it uses natural stimuli (e.g., fear of novel open spaces and fear of balancing on a relatively narrow, raised platform) that can induce anxiety in humans [17]. In the present study, oral administration of Lippia multiflora aqueous extracts increased the percentage of entries into and time spent in the open arms of the elevated plus maze, while it decreased the percentage of time spent on the closed arms. An increase in the percentage of entries into and time spent in the open arms refers to a decrease in anxiety $[28,29]$ and a decrease in these behavioural parameters in closed arms reflects a reduction in stress $[17,19,28]$. These results indicate that Lippia multiflora aqueous extracts has anxiolytic-like activity. Dysregulation of the GABAergique, serotoninergic, dopaminergic and adrenergic neuro-systems have all been implicated in the pathophysiology of anxiety [30-32].

To further understand the role of each of the serotoninergic receptors in the mechanism of action of Lippia multiflora aqueous extracts, different serotoninergic ligands were tested in the elevated plus maze. mCPP, a partial 5- $\mathrm{HT}_{2 \mathrm{C} / 2 \mathrm{~B}}$ receptor agonist, by significantly antagonising the anxiolytic-like activity of Lippia multiflora confirmed the involvement of this receptor in mediating these properties in the elevated plus maze [33]. To date, the only selective high affinity antagonist of 5- $\mathrm{HT}_{1 \mathrm{~A}}$ receptors is WAY-100635 stimulate excitability, locomotion and anxiety in rodents acclimatised to their environment and alter their behaviour [34, 35]. Lippia multiflora aqueous extract produced potent anxiolytic-like effects in elevated plus maze test. However, these anxiolytic properties were completely blocked by WAY-100635. These results suggest that the anxiolytic-like effects of Lippia multiflora might be mediated by 5-HT $1 \mathrm{~A}$ receptors [35]. Several results obtained from the literature suggest the involvement of forebrain $5-\mathrm{HT}_{2}$ receptor signaling in stress-related psychiatric conditions. For example, activation of 5- $\mathrm{HT}_{2} \mathrm{C}$ receptors in the amygdala during traumatic stress is necessary for the expression of anxiety-like behaviours after traumatic stress exposure [36]. We studied the involvement of 5-HT 2 receptors in the anxiolytic-like effects of Lippia multiflora aqueous extract by co-treating mice with DOI (a 5-HT2A/2C receptor agonist) and the plant aqueous extract. DOI appeared to antagonise the effect of the higher dose of Lippia multiflora aqueous extract, interestingly with statistical significance. The use of DOI confirmed the involvement of the $5-\mathrm{HT}_{2 \mathrm{~A} / 2 \mathrm{C}}$ receptor in the pharmacological properties of Lippia multiflora [36].

The open filed test is based on rodents' innate aversion to brightly illuminated open areas and spontaneous exploratory behaviour in response to mild stressors (i.e., a novel environment and light). The effects of classic anxiolytics (e.g., benzodiazepines) and newer anxiolytic-like agents (e.g., serotoninergic drugs or drugs that act on neuropeptide receptors) can be detected with this paradigm [18, 28,37]. Our results showed that Lippia multiflora aqueous extracts significantly increased the number of crossing, grooming and the centre time in the open field test indicating that Lippia multiflora corroborating anxiolytic-like effect previously shown in the elevated plus maze test. These results indicate that Lippia multiflora has anxiolytic-like activity [18, 28, 37]. The results obtained in the open field test indicated that one hour after the acute oral administration of Lippia multiflora aqueous extracts at the doses ranged from 23.70 to $230.78 \mathrm{mg} / \mathrm{kg}$ in mice, the endogenous levels of noradrenaline, dopamine and serotonin in the brain homogenates remain comparable to that distilled water-treated animals. 


\section{Conclusion}

To summarize, the data presented here indicate that Lippia multiflora aqueous extracts induced anxiolytic-like effects in the plus-maze test and open field test. The anxiolytic effects of Lippia multiflora appear to be mediated by 5-HT2C/2B, 5- $\mathrm{HT}_{1 \mathrm{~A}}$, and 5- $\mathrm{HT}_{2 \mathrm{~A} / 2 \mathrm{C}}$ receptors, respectively. The results obtained from the neurochemical studies suggest that these effects are not mediated through the modulation of monoamine neurotransmitter levels when Lippia multiflora is administered once. The present results suggest the potential usefulness of Lippia multiflora for the treatment of anxiety disorders.

\section{Compliance with ethical standards}

\section{Acknowledgments}

The authors are very thankful to LabEx Physiology, Pharmacological Targets and Therapeutics, University of Buea, Cameroon, for supporting us by providing apparatus and drugs.

\section{Disclosure of conflict of interest}

The authors declare that they have no conflict of interest.

\section{Statement of ethical approval}

The protocols were performed in concordance with the International Guide for the Care and Use of Laboratory Animal (National Institute of Health; publication No. 85-23, revised 1996) and the Cameroon National Ethical Committee, Yaounde (No. FW-IRB00001954).

\section{References}

[1] Pelissolo A. Troubles anxieux et névrotiques. EMC-AKOS Traité Médecine. 2012; 1-11.

[2] Boyd CP, Gullone E, Kostanski M, Ollendick TH, Shek DT. Prevalence of anxiety and depression in Australian adolescents: Comparisons with worldwide data. The Journal of Genetic Psychology. 2000; 161(4): 479-92.

[3] Costello EJ, Mustillo S, Erkanli A, Keeler G, Angold A. Prevalence and development of psychiatric disorders in childhood and adolescence. Archives of general psychiatry. 2003; 60(8): 837-44.

[4] Nemeroff CB. The role of GABA in the pathophysiology and treatment of anxiety disorders. Psychopharmacology bulletin. 2003; 37(4): 133-46.

[5] Taïwe G, Bum E, Dimo T, Talla E, Weiss N, Dawe A, et al. Antidepressant, myorelaxant and anti-anxiety-like effects of Nauclea latifolia smith (Rubiaceae) roots extract in murine models. International journal of pharmacology. 2010; 6(4): 364-71.

[6] Saad S. Administration of CNS depressant drugs like barbiturates, hydantoin and diazepam etc. can restore the isoniazid induced fall in brain GABA levels. J Pharm Pharmacol. 1972; 24: 839-40.

[7] Ninan PT. The functional anatomy, neurochemistry, and pharmacology of anxiety. Journal of Clinical Psychiatry. 1999; 60: 12-7.

[8] Hoyer D, Martin G. 5-HT receptor classification and nomenclature: towards a harmonization with the human genome. Neuropharmacology. 1997; 36(4-5): 419-28.

[9] Feighner JP, Boyer WF. Serotonin-1A anxiolytics: an overview. Psychopathology. 1989; 22(Suppl. 1): 21-6.

[10] Heisler LK, Chu H-M, Brennan TJ, Danao JA, Bajwa P, Parsons LH, et al. Elevated anxiety and antidepressant-like responses in serotonin 5-HT1A receptor mutant mice. Proceedings of the National Academy of Sciences. 1998; 95(25): 15049-54.

[11] Adjanohoun É. Contribution aux études ethnobotaniques et floristiques au Togo: rapport présenté à l'ACCT: Agence de coopération culturelle et technique. 1986.

[12] Akoegninou A, Adjanohoun E, Adjakidje M, Ahyi L, Ake Assi A, Akoegninou J, et al. Contribution aux études ethnobotaniques et floristiques en République Populaire du Bénin. Médecine traditionnelle et pharmacopée Agence de coopération culturelle et technique, (ACCT), Paris. 1989; 895. 
[13] Arbonnier M. Arbres, arbustes et lianes des zones sèches d'Afrique de l'Ouest: Editions Quae. 2009.

[14] González-Trujano ME, Hernández-Sánchez LY, Muñoz Ocotero V, Dorazco-González A, Guevara Fefer P, AguirreHernández E. Pharmacological evaluation of the anxiolytic-like effects of Lippia graveolens and bioactive compounds. Pharmaceutical biology. 2017; 55(1): 1569-76.

[15] Percie du Sert N, Hurst V, Ahluwalia A, Alam S, Avey MT, Baker M, et al. The ARRIVE guidelines 2.0: Updated guidelines for reporting animal research. Journal of Cerebral Blood Flow \& Metabolism. 2020; 40(9): $1769-77$.

[16] Organization WH. General guidelines for methodologies on research and evaluation of traditional medicine. World Health Organization. 2000.

[17] Lister RG. The use of a plus-maze to measure anxiety in the mouse. Psychopharmacology. 1987; 92(2): 180-5.

[18] Bourin M, Petit-Demoulière B, Nic Dhonnchadha B, Hascöet M. Animal models of anxiety in mice. Fundamental \& clinical pharmacology. 2007; 21(6): 567-74.

[19] Bum EN, Taïwe GS, Moto F, Ngoupaye G, Nkantchoua G, Pelanken M, et al. Anticonvulsant, anxiolytic, and sedative properties of the roots of Nauclea latifolia Smith in mice. Epilepsy \& Behavior. 2009; 15(4): 434-40.

[20] Kim C, Speisky M, Kharouba S. Rapid and sensitive method for measuring norepinephrine, dopamine, 5hydroxytryptamine and their major metabolites in rat brain by high-performance liquid chromatography: differential effect of probenecid, haloperidol and yohimbine on the concentrations of biogenic amines and metabolites in various regions of rat brain. Journal of Chromatography A. 1987; 386: 25-35.

[21] Rex A, Morgenstern E, Fink H. Anxiolytic-like effects of Kava-Kava in the elevated plus maze test-a comparison with diazepam. Progress in Neuro-Psychopharmacology and Biological Psychiatry. 2002; 26(5): 855-60.

[22] Faustino TT, Almeida RBd, Andreatini R. Medicinal plants for the treatment of generalized anxiety disorder: a review of controlled clinical studies. Brazilian Journal of Psychiatry. 2010; 32(4): 429-36.

[23] Hilakivi-Clarke L, Turkka J, Lister R, Linnoila M. Effects of early postnatal handling on brain $\beta$-adrenoceptors and behavior in tests related to stress. Brain research. 1991; 542(2): 286-92.

[24] Liu Z, Silva J, Shao AS, Liang J, Wallner M, Shao XM, et al. Flavonoid compounds isolated from Tibetan herbs, binding to GABAA receptor with anxiolytic property. Journal of Ethnopharmacology. 2021; 267: 113630.

[25] Karim N, Jia Z, Zheng X, Cui S, Chen W. A recent review of citrus flavanone naringenin on metabolic diseases and its potential sources for high yield-production. Trends in Food Science \& Technology. 2018; 79: 35-54.

[26] Antunes MS, Cattelan Souza L, Ladd FVL, Ladd AABL, Moreira AL, Bortolotto VC, et al. Hesperidin Ameliorates Anxiety-Depressive-Like Behavior in 6-OHDA Model of Parkinson's Disease by Regulating Striatal Cytokine and Neurotrophic Factors Levels and Dopaminergic Innervation Loss in the Striatum of Mice. Molecular Neurobiology. 2020; 57: 3027-41.

[27] Pellow S, Chopin P, File SE, Briley M. Validation of open: closed arm entries in an elevated plus-maze as a measure of anxiety in the rat. Journal of neuroscience methods. 1985; 14(3): 149-67.

[28] Bum EN, Soudi S, Ayissi E, Dong C, Lakoulo N, Maidawa F, et al. Anxiolytic activity evaluation of four medicinal plants from Cameroon. African Journal of Traditional, Complementary and Alternative Medicines. 2011; 8(5S).

[29] Moto FC, Arsa'a A, Ngoupaye GT, Taiwe GS, Njapdounke JS, Kandeda AK, et al. Anxiolytic and antiepileptic properties of the aqueous extract of Cissus quadrangularis (Vitaceae) in mice pilocarpine model of epilepsy. Frontiers in pharmacology. 2018; 9: 751.

[30] Bielau H, Steiner J, Mawrin C, Truebner K, Brisch R, MEYER-LOTZ G, et al. Dysregulation of GABAergic neurotransmission in mood disorders: a postmortem study. Annals of the New York Academy of Sciences. 2007; 1096(1): 157-69.

[31] Ressler KJ, Nemeroff CB. Role of serotonergic and noradrenergic systems in the pathophysiology of depression and anxiety disorders. Depression and anxiety. 2000; 12(S1): 2-19.

[32] Rincón-Cortés M, Gagnon KG, Dollish HK, Grace AA. Diazepam reverses increased anxiety-like behavior, social behavior deficit, and dopamine dysregulation following withdrawal from acute amphetamine. Neuropsychopharmacology. 2018; 43(12): 2418-25.

[33] Bourin M, Dhonnchadha BdÁN, Colombel MC, Dib M, Hascoët M. Cyamemazine as an anxiolytic drug on the elevated plus maze and light/dark paradigm in mice. Behavioural brain research. 2001; 124(1): 87-95. 
[34] Forster EA, Cliffe IA, Bill DJ, Dover GM, Jones D, Reilly Y, et al. A pharmacological profile of the selective silent 5HT1A receptor antagonist, WAY-100635. European journal of pharmacology. 1995; 281(1): 81-8.

[35] Martínez-Mota L, Estrada-Camarena E, López-Rubalcava C. Indorenate produces antidepressant-like actions in the rat forced swimming test via 5-HT 1A receptors. Psychopharmacology. 2002; 165(1): 60-6.

[36] Harada K, Yamaji T, Matsuoka N. Activation of the serotonin 5-HT2C receptor is involved in the enhanced anxiety in rats after single-prolonged stress. Pharmacology Biochemistry and Behavior. 2008; 89(1): 11-6.

[37] Taïwe GS, Bum EN, Talla E, Dimo T, Sidiki N, Dawe A, et al. Evaluation of antinociceptive effects of Crassocephalum bauchiense Hutch (Asteraceae) leaf extract in rodents. Journal of Ethnopharmacology. 2012; 141(1): $234-41$. 